\title{
Antitussive and antibronchoconstriction actions of fenspiride in guinea-pigs
}

\author{
E.A. Laude*, D. Bee*, O. Crambes**, P. Howard*
}

\begin{abstract}
Antitussive and antibronchoconstriction actions of fenspiride in guinea-pigs. E.A. Laude, D. Bee, O. Crambes, P. Howard. CERS Journals Ltd 1995.

ABSTRACT: Fenspiride is a nonsteriodal anti-inflammatory agent, which we have previously shown to have an in vivo antibronchoconstrictor action in guinea pigs. We have currently studied this action using the constrictors Substance P, neurokinin A, citric acid and capsaicin in anaesthetized guinea-pigs. Fenspiride has also been reported to produce a subjective improvement in cough in patients. We have used a conscious guinea-pig model of cough as a more definitive method to study the effect of fenspiride on capsaicin- and citric acid-induced cough.

Aerosolized fenspiride $\left(1 \mathrm{mg} \cdot \mathrm{mL}^{-1}\right)$ caused a $58 \%$ reversal of capsaicin-induced bronchoconstriction; and i.v. fenspiride $\left(1 \mathrm{mg} \cdot \mathrm{kg}^{-1}\right)$ a $45 \%$ reversal of citric acid induced bronchoconstriction. Substance P- and neurokinin A-induced bronchoconstriction were unaffected by $1 \mathrm{mg}^{\circ} \mathrm{kg}^{-1}$ i.v. fenspiride. Aerosolized fenspiride $(1,3$ and $\left.10 \mathrm{mg} \cdot \mathrm{mL}^{-1}\right)$ administered for $4 \mathrm{~min}$ reduced citric acid $(300 \mathrm{mM})$ induced cough, but $0.1 \mathrm{mg} \cdot \mathrm{mL}^{-1}$ was without effect. Pretreatment with aerosolized fenspiride $\left(10 \mathrm{mg} \cdot \mathrm{mL}^{-1}\right)$ caused a shift in the citric acid dose response curve to the right. For citric acid-induced cough, the duration of action of aerosolized fenspiride (10 $\mathrm{mg} \cdot \mathrm{mL}^{-1}$ ) was found to be 5 and 15 min post-treatment. Aerosolized capsaicin (30 $\mu \mathrm{M})$ induced cough was also reduced by 3 and $10 \mathrm{mg} \cdot \mathrm{mL}^{-1}$ aerosolized fenspiride, but no significant effect was found with $1 \mathrm{mg} \cdot \mathrm{mL}^{-1}$.

We conclude that aerosolized fenspiride reduces capsaicin- and citric acid-induced bronchoconstriction as well as induced cough in guinea-pigs in vivo. Whether a pathway common to both cough and bronchoconstriction is the site of action of fenspiride remains to be established. We postulate that fenspiride, acting as an antitussive and antibronchoconstrictor agent, would be beneficial in the clinical situation for those patients with hyperresponsive airways.

Eur Respir J., 1995, 8, 1699-1704.
\end{abstract}

*Dept of Medicine, University of Sheffield, Sheffield, UK. **Institut de Recherches Internationales, Servier, Paris, France.

Correspondence: E.A. Laude

Dept of Experimental Medicine University of Sheffield

Beech Hill Rd

Sheffield S10 2RX

UK

Keywords: Bronchoconstriction capsaicin

citric acid

cough

neurokinin A

substance $\mathrm{P}$

Received: October 311994

Accepted after revision June 81995
Fenspiride (Pneumorel ${ }^{\circledR}$, Biopharma, France) is a nonsteroidal anti-inflammatory agent that may have an important role in reversible obstructive airways disease. The anti-inflammatory properties have proved effective in experimentally-induced inflammation [1], and possibly in the clinical stituation [2].

The anti-inflammatory action has been attributed to an anti-free radical effect and an inhibition of cyclooxygenase metabolism [1, 3]. It has also been shown to have a weak antihistamine (H1) activitity [1] and may, by this action, influence numerous pulmonary functions, including bronchoconstriction and allergic responses. Anti-allergic properties have been demonstrated in vivo in allergic rhinitis in man [4], and in allergic bronchospasm in guinea-pigs [5]. Anti-bronchoconstrictor activity has been recorded in vitro in guinea-pig tracheal rings reversing induced constriction to a number of agents, including histamine and substance $\mathrm{P}$ [1].

In a double-blind, placebo-controlled study in mild chronic obstructive pulmonary disease, patients improved their forced expiratory volume in one second (FEV1) and arterial oxygen tension $\left(\mathrm{Pa}_{\mathrm{a}} \mathrm{O}_{2}\right)$ after 6 months treatment with fenspiride [6]. There was also a significant subjective improvement in cough and sputum production. These patients may have possessed an undocumented component of their disease which was reversible, and BEE et al. [7] have suggested that the improvement in blood gases with fenspiride treatment may be due not only to an alleviation of inflammation but also to a bronchodilator action. They showed that with acute treatment, although there was no change in ventilation or pulmonary blood flow, fenspiride was able to reverse the bronchoconstriction induced by capsaicin in guinea-pigs in vivo.

Capsaicin promotes the release of neurokinins from sensory bronchial C-fibres [8], which can then cause bronchoconstriction. In the guinea-pig, stimulation of neurokinin receptor sites $\left(\mathrm{NK}_{2}\right)$ produces bronchoconstriction [9]. In this study, we have investigated the acute action of fenspiride on bronchoconstriction induced by the tachykinins, substance $\mathrm{P}$ (SP) and neurokinin A (NKA), in order to determine whether fenspiride's reversal of 
capsaicin-induced bronchoconstriction could occur via an inhibitory action on neurokinin receptors.

Capsaicin is a commonly used tussive agent in cough challenge studies both in guinea-pigs [10] and man [11], probably exerting its tussive effect via an action on sensory C-fibres. We have used a guinea-pig model of capsaicin- and citric acid-induced cough as a more definitive technique to investigate the antitussive properties of fenspiride, indicated by the subjective improvement in cough noted by AKoun et al. [6] in patients.

\section{Methods}

\section{Airways resistance}

Dunkin Hartley guinea-pigs (450-550 g) were anaesthetized with intraperitoneal urethane $\left(1.5 \mathrm{~g} \cdot \mathrm{kg}^{-1}\right)$. Intravenous infusions and bolus i.v. injections were introduced via a jugular cannula. Pleural pressure was measured via a pleural cannula placed between the 5th and 6th ribs, and airflow was measured from a tracheal cannula. The animals were allowed to breathe spontaneously. A voltage proportional to lung volume was subtracted from the pleural pressure, and the resulting pressure signal fed into one axis of an X-Y recorder whilst the airflow signal was fed into the other axis. Total airways resistance (Raw) was calculated from the slope of the pressure flow loops.

Aerosols produced by an ultrasonic nebulizer (Ultra Neb 99, DeVilbis, UK; output $0.4 \mathrm{~mL} \cdot \mathrm{min}^{-1}$ and 0.5 $5 \mu \mathrm{m}$ particle size, manufacturers specification) were held in a spacer $(850 \mathrm{~mL})$ filled for $1 \mathrm{~min}$ at a rate of 1 $\mathrm{L} \cdot \mathrm{min}^{-1}$, and the animals were allowed to breath spontaneously from this via the tracheal cannula. Capsaicin $(30 \mu \mathrm{M}$ for $30 \mathrm{~s})$ and citric acid $(500 \mathrm{mM}$ for $30 \mathrm{~s})$ were administered in this manner. When a stable increase in $R$ aw was attained with the constrictor agent, fenspiride (aerosol $1 \mathrm{mg} \cdot \mathrm{mL}^{-1}$ or i.v. $1 \mathrm{mg} \cdot \mathrm{kg}^{-1}$ ) was given. Substance $\mathrm{P}$ was administered as a $5 \mu \mathrm{g} i$.v. bolus dose before, during and after a $10 \mathrm{~min}$ infusion of $50 \mu \mathrm{g} \cdot \mathrm{min}^{-1}$ fenspiride. Neurokinin A was administered as a $0.2 \mu \mathrm{g} \cdot \mathrm{min}^{-1}$ continuous i.v. infusion, and a bolus $i . v$. dose of $1 \mathrm{mg} \cdot \mathrm{kg}^{-1}$ fenspiride was administered after a stable $R$ aw was attained.

\section{Cough}

Conscious male Dunkin Hartley guinea-pigs (350-500 g) were used. The method used to measure cough was adapted from that of FosBerg et al. [12]. Each animal was placed in a perspex chamber $(850 \mathrm{~mL})$ with an air inlet and outlet. Air was passed continuously through the chamber at a rate of $1 \mathrm{~L} \cdot \mathrm{min}^{-1}$. The changes in airflow were measured by a pneumotachograph (Fleisch $0.6 \mathrm{~V}$ ) connected to the outflow and recorded on a fast response recorder (Reba UK; Par 1000). The aerosols were generated by an ultrasonic nebulizer (DeVilbis; Ultra Neb 99) and introduced into the airflow at a rate of $0.4 \mathrm{~mL} \cdot \mathrm{min}^{-1}$ ( particle size $\left.0.5-5 \mu \mathrm{m}\right)$. The animal was allowed to acclimatize for $10 \mathrm{~min}$, and was then subjected to either active or vehicle ( $0.9 \%$ saline) aerosols for $4 \mathrm{~min}$. This was followed $1 \mathrm{~min}$ later by a tussive challenge of either citric acid or capsaicin $(30 \mu \mathrm{M})$ for $2 \mathrm{~min}$. The number of coughs generated over the following $10 \mathrm{~min}$ was counted.

Tussive challenges were carried out at least $24 \mathrm{~h}$ apart, i.e. saline pretreatment was carried out on one day, fenspiride pretreatment $24 \mathrm{~h}$ later, followed by saline pretreatment $24 \mathrm{~h}$ later to ensure that the baseline cough response remained unchanged.

Dose response curves to citric acid were constructed using the responses to 100,300 and $500 \mathrm{mM}$ citric acid dissolved in $0.9 \%$ saline. Those for aerosolized fenspiride used $0.1,1,3$ and $10 \mathrm{mg} \cdot \mathrm{mL}^{-1}$ fenspiride in $0.9 \%$ saline with tussive challenges to $300 \mathrm{mM}$ citric acid and $30 \mu \mathrm{M}$ capsaicin. Capsaicin was dissolved initially in absolute ethanol and then diluted 1:100 in saline for nebulization.

A cough was defined as a short-lived wide excursion from baseline on the airflow trace approximately twice that resulting from a deep breath or sigh and much greater than that due to movements of the animal. A sneeze produced the same excursion as a cough and the two were differentiated by observation of the animal. Cough frequency was expressed as number of coughs per $10 \mathrm{~min}$.

In some animals, especially after capsaicin challenge, slow laboured breathing was observed. This was alleviated by administering aerosolized terbutaline $\left(0.2 \mathrm{mg} \cdot \mathrm{mL}^{-1}\right)$ after tussive challenge.

\section{Statistical analysis}

The results are expressed as the mean \pm standard error of the mean (SEM). Statistical analysis was carried out using paired Student's t-test.

\section{Results}

\section{Airways resistance}

Table 1 gives the airways resistance values (mean \pm SEM) in guinea-pigs before and at sustained maximum constriction and following fenspiride administration at maximum constriction.

Capsaicin. Aerosolized capsaicin ( $30 \mu \mathrm{M}$ for $30 \mathrm{~s}$; $\mathrm{n}=6)$ consistently produced a maintained increase $(\mathrm{p}<0.01)$ in airways resistance from $5.2 \pm 0.42$ to $15.0 \pm 1.34 \mathrm{mmHg} \cdot \mathrm{L}^{-1} \cdot \mathrm{min}$. Fenspiride aerosol $\left(1 \mathrm{mg} \cdot \mathrm{mL}^{-1}\right)$ significantly $(\mathrm{p}<0.05)$ reduced $R$ aw to $9.4 \pm 1.67 \mathrm{mmHg} \cdot \mathrm{L}^{-1} \cdot \mathrm{min}$, a reduction of $58 \%$. The reduction developed $2 \mathrm{~min}$ from the beginning of fenspiride administration.

Citric acid. Aerosolized citric acid $(500 \mathrm{mM}$ for $30 \mathrm{~s}$; $\mathrm{n}=6)$ significantly $(\mathrm{p}<0.01)$ increased $R$ aw from $7.3 \pm 1.14$ to $23.1 \pm 4.49 \mathrm{mmHg} \cdot \mathrm{L}^{-1} \cdot \mathrm{min}$. A maximum increase was reached after $5 \mathrm{~min}$, and was stable for $30 \mathrm{~min}$. Fenspiride $\left(1 \mathrm{mg} \cdot \mathrm{kg}^{-1}\right.$ i.v. bolus injection) significantly $(\mathrm{p}<0.05)$ reversed this increase to $14.7 \pm 2.74 \mathrm{mmHg} \cdot \mathrm{L}^{-1} \cdot \mathrm{min}$, a $45 \%$ reduction. 
Table 1. - The effect of fenspiride on the increased airways resistance induced by bronchoconstrictor agents

\begin{tabular}{|c|c|c|c|c|}
\hline \multirow[b]{2}{*}{ Constrictor } & \multicolumn{3}{|c|}{ Airways resistance $\mathrm{mmHg} \cdot \mathrm{L}^{-1} \cdot \min$} & \multirow[b]{2}{*}{ Dose Fenspiride } \\
\hline & Basal & Constricted & Fenspiride & \\
\hline $\begin{array}{l}\text { Capsaicin }(\mathrm{n}=6) \\
30 \mu \mathrm{M}, 30 \mathrm{~s}\end{array}$ & $5.2(0.42)$ & $15.0(1.34)^{* *}$ & $9.4(1.67)^{*}$ & $1 \mathrm{mg} \cdot \mathrm{mL}^{-1}$ aerosol \\
\hline $\begin{array}{r}\text { Citric acid }(\mathrm{n}=6) \\
500 \mathrm{mM}, 30 \mathrm{~s}\end{array}$ & $7.3(1.14)$ & $23.1(4.5)^{* *}$ & $14.7(2.74)^{*}$ & $1 \mathrm{mg} \cdot \mathrm{kg}^{-1} i . v$. bolus \\
\hline $\begin{array}{l}\text { Neurokinin } \mathrm{A}(\mathrm{n}=8) \\
0.2 \mu \mathrm{g} \cdot \mathrm{min}^{-1} \text { i.v. infusion }\end{array}$ & $6.1(1.01)$ & $17.8(2.03)^{* *}$ & $16.4 \quad(2.27)$ & $1 \mathrm{mg} \cdot \mathrm{kg}^{-1}$ i.v. bolus \\
\hline $\begin{array}{l}\text { Substance } \mathrm{P}(\mathrm{n}=12) \\
5 \mu \mathrm{g} \text { i.v. bolus }\end{array}$ & $5.7(1.0)$ & $21.9(7.5)^{* *}$ & $26.9(12.4)$ & $50 \mu \mathrm{g} \cdot \min ^{-1} i . v$. infusion \\
\hline
\end{tabular}

$5 \mu \mathrm{g} i . v$. bolus

Data are presented as the mean (SEM) of the number of animals $(n) . *: p<0.05$, compared to constricted; **: $p<0.01$, compared to

Substance $P$. SP given as a $5 \mu \mathrm{g} i . v$. bolus injection $(\mathrm{n}=$ 12) significantly $(\mathrm{p}<0.01)$ increased $R$ aw from $5.7 \pm 1.0$ to $21.9 \pm 7.5 \mathrm{mmHg} \cdot \mathrm{L}^{-1} \cdot \mathrm{min}$. The action of SP was transient, lasting approximately $2 \mathrm{~min}$. The mean Raw achieved with SP during an infusion of $50 \mu \mathrm{g} \cdot \mathrm{min}^{-1}$ fenspiride for $10 \mathrm{~min}$ was $26.9 \pm 12.4 \mathrm{mmHg} \cdot \mathrm{L}^{-1} \cdot \mathrm{min}$. Although this value was higher, it was not significantly different to the value found in the absence of fenspiride $(21.9 \pm 7.5 \mathrm{mmHg}$. $\left.\mathrm{L}^{-1} \cdot \min \right)$. This reflects a potentiation effect of SP, i.e. successive injections giving larger increases in $R$ aw.

Neurokinin A. NKA was given as a continuous i.v. infusion $\left(1 \mu \mathrm{g} \cdot \mathrm{min}^{-1} ; \mathrm{n}=8\right)$ which significantly $(\mathrm{p}<0.01)$ increased $R$ aw from $6.1 \pm 1.01$ to $17.8 \pm 2.03 \mathrm{mmHg} \cdot \mathrm{L}^{-1} \cdot \mathrm{min}$. A maximum response was attained $20 \mathrm{~min}$ after the start of the infusion. Injections of $1 \mathrm{mg} \cdot \mathrm{kg}^{-1} i . v$. fenspiride were unable to significantly reduce the NKA induced increase in Raw.

\section{Cough}

None of the animals coughed on aerosolized saline exposure and, therefore, were not excluded from the series of experiments because of suspected hyperreactivity or infection. No adverse behavioural effects or change in depth or rate of airflow trace were noted on administration of aerosols of fenspiride.

Citric acid-induced cough - dose response curve. A dose response curve of the cough frequency (mean \pm SEM) with increasing concentrations of citric acid is shown in figure 1. Fenspiride $10 \mathrm{mg} \cdot \mathrm{mL}^{-1}$ pretreatment $(\mathrm{n}=10)$ for 4 min significantly reduced $(\mathrm{p}<0.01)$ the cough frequency from $6.9 \pm 1.6$ to $2.4 \pm 1.3$ coughs $\cdot 10 \mathrm{~min}^{-1}$ at $100 \mathrm{mM}$, from $18.2 \pm 2.1$ to $14.6 \pm 1.7 \mathrm{cough} \cdot 10 \mathrm{~min}^{-1}$ at $300 \mathrm{mM}$, and from $23.0 \pm 2.0$ to $18.7 \pm 1.9$ coughs $\cdot 10 \mathrm{~min}^{-1}$ at 500 $\mathrm{mM}$ citric acid, respectively. This shifted the dose-response curve of citric acid to the right.

Dose response to fenspiride pretreatment. Aerosolized fenspiride significantly $(\mathrm{p}<0.01)$ reduced the cough frequency of citric acid-induced cough $(300 \mathrm{mM})$ from $15.7 \pm 1.8$ to $12.1 \pm 2.1$ coughs $\cdot 10 \mathrm{~min}^{-1}$ with $1 \mathrm{mg} \cdot \mathrm{mL}^{-1}$, from $19.3 \pm 3.8$ to $12.6 \pm 3.7$ coughs $\cdot 10 \mathrm{~min}^{-1}$ with $3 \mathrm{mg} \cdot \mathrm{mL}^{-1}$, and from $20.8 \pm 3.2$ to $14.4 \pm 2.9$ coughs $\cdot \mathrm{min}^{-1}$ with 10 $\mathrm{mg} \cdot \mathrm{mL}^{-1}$ (fig 2). These gave reductions of 23, 35 and $31 \%$, respectively. Maximum effect was achieved with $3 \mathrm{mg} \cdot \mathrm{mL}^{-1}$ and was maintained with $10 \mathrm{mg} \cdot \mathrm{mL}^{-1}$. Pretreatments with 1,3 and $10 \mathrm{mg} \cdot \mathrm{mL}^{-1}$ were carried out on the same group of animals $(n=12)$, and the cough frequency in response to $300 \mathrm{mM}$ citric acid after pretreatment with saline showed no significant change throughout the procedures. Pretreatments with 0.1

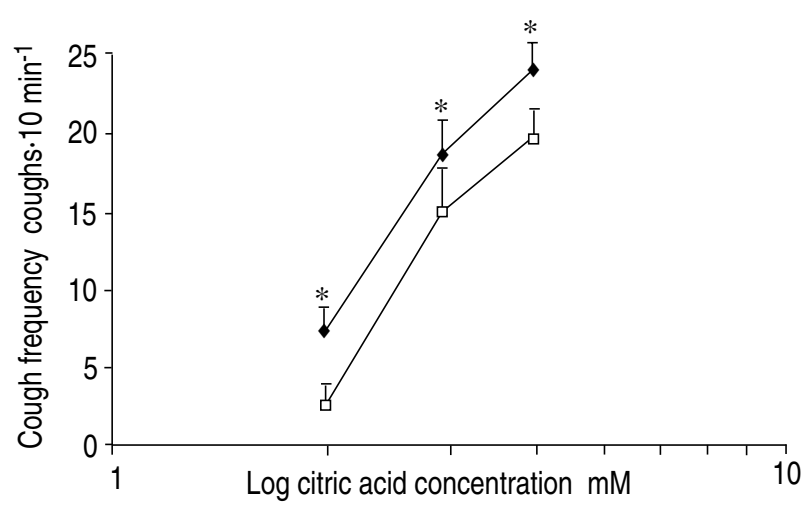

Fig. 1. - Cough frequency in response to 100,300 and $500 \mathrm{mM}$ citric acid in 10 guinea-pigs exposed to aerosols of $0.9 \%$ saline or 10 $\mathrm{mg} \cdot \mathrm{mL}^{-1}$ fenspiride for $4 \mathrm{~min}$. Values are presented as mean and SEM. $\diamond$ : saline; $\square$ : fenspiride. $*$ : $\mathrm{p}<0.01$, compared to saline.

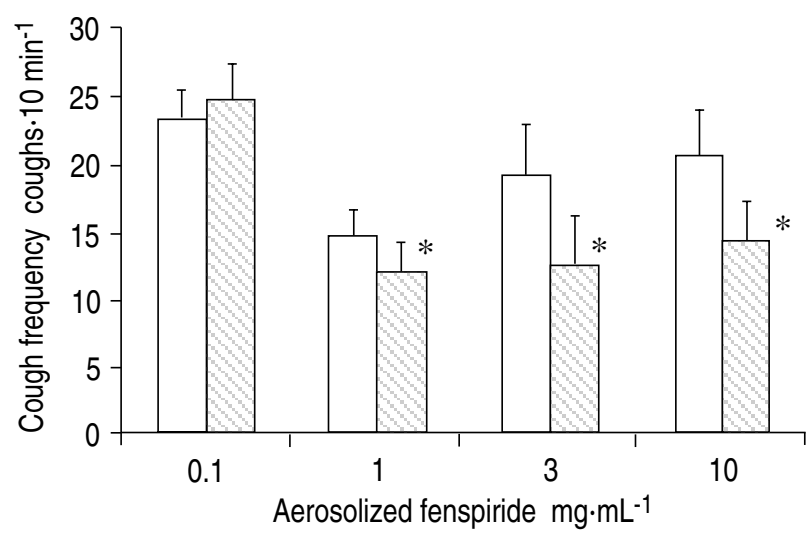

Fig. 2. - Cough frequency of citric acid-induced cough $(300 \mathrm{mM}) 1$ min after exposure to $4 \mathrm{~min}$ aerosolized fenspiride. Values are presented as mean and SEM. The same group of 12 guinea-pigs was exposed to 1,3 and $10 \mathrm{mg} \cdot \mathrm{mL}^{-1}$ fenspiride; and a second group of 11 animals was exposed to $0.1 \mathrm{mg} \cdot \mathrm{mL}^{-1}$ fenspiride. $\square$ : saline; 0 : fenspiride. *: $\mathrm{p}<0.01$ compared to saline. 
$\mathrm{mg} \cdot \mathrm{mL}^{-1}$ were carried out on a separate group of animals $(\mathrm{n}=11)$, which gave a higher mean cough frequency $(23.4 \pm$ 1.9 coughs $\cdot 10 \mathrm{~min}^{-1}$ ) demonstrating a greater sensitivity to citric acid in this group. However, they showed no significant reduction in cough frequency with $0.1 \mathrm{mg} \cdot \mathrm{mL}^{-1}$ fenspiride pretreatment $\left(24.7 \pm 2.7\right.$ coughs $\left.\cdot 10 \mathrm{~min}^{-1}\right)$.

Capsaicin-induced cough. Capsaicin $(30 \mu \mathrm{M})$ induced a mean cough frequency of $16.4 \pm 5.2$ coughs $\cdot 10 \mathrm{~min}^{-1}$ $(n=9)$. This was significantly $(\mathrm{p}<0.01)$ reduced by $52 \%$ to $7.9 \pm 2.8 \mathrm{cough} \cdot 10 \mathrm{~min}^{-1}$ by 4 min pretreatment with 3 $\mathrm{mg} \cdot \mathrm{mL}^{-1}$ aerosolized fenspiride. In the same group of animals, $1 \mathrm{mg} \cdot \mathrm{mL}^{-1}$ pretreatment gave frequencies that were not significantly different to control values. In a separate group of animals $(n=9)$, pretreatment with 4 min aerosolized $10 \mathrm{mg} \cdot \mathrm{mL}^{-1}$ fenspiride significantly $(\mathrm{p}<0.002)$ reduced cough from $11.6 \pm 1.7$ to $6.7 \pm 1.4$ coughs. $10 \mathrm{~min}^{-1}$, a $51 \%$ reduction (fig. 3 ).

Duration of fenspiride action. Challenge with citric acid 1 min after pretreatment with $10 \mathrm{mg} \cdot \mathrm{mL}^{-1}$ aerosolized fenspiride showed a significant $(\mathrm{p}<0.05)$ reduction in

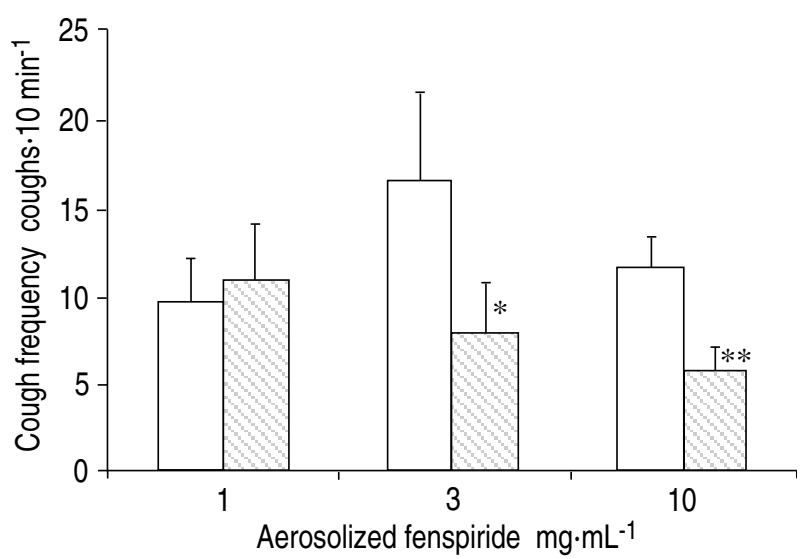

Fig. 3. - Cough frequency of capsaicin-induced cough $(30 \mu \mathrm{M})$ in guinea-pigs exposed to aerosols of $0.9 \%$ saline and fenspiride; 9 received 1 and $3 \mathrm{mg} \cdot \mathrm{mL}^{-1}$ and a second group of 9 received $10 \mathrm{mg} \cdot \mathrm{mL}^{-1}$. Values are presented as mean and SEM. $\square$ : saline; $\mathbf{3}$ : fenspiride. ${ }^{*}: \mathrm{p}<0.01$; **: $\quad \mathrm{p}<0.002$, compared to saline.

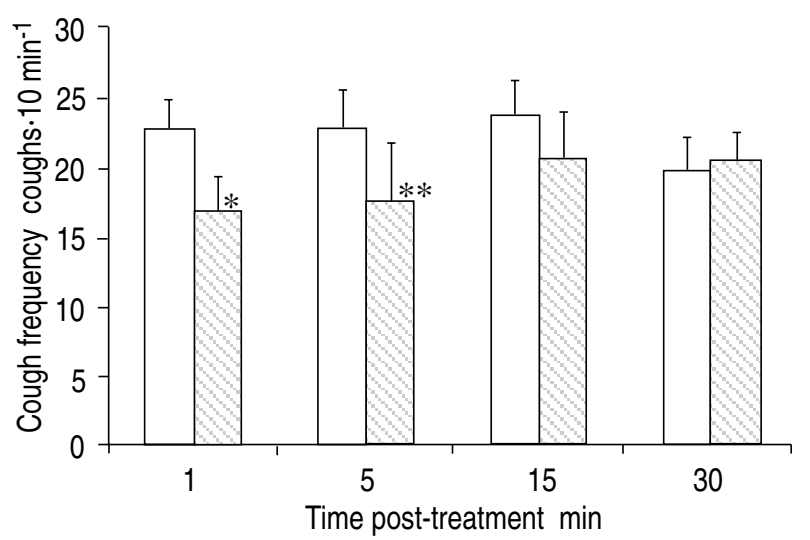

Fig. 4. - Cough frequency of citric acid-induced cough of 11 guineapigs, 1, 5, 15 and $30 \mathrm{~min}$ after exposure to aerosols of saline or 10 $\mathrm{mg} \cdot \mathrm{mL}^{-1}$ fenspiride for $4 \mathrm{~min}$. Values are presented as mean and SEM. $\square: 0.9 \%$ saline; 8 : fenspiride. $*: \mathrm{p}<0.05$; **: $\mathrm{p}<0.01$ compared to saline. cough frequency from $22.8 \pm 2.0$ (control) to $16.9 \pm 2.4$ coughs $10 \mathrm{~min}^{-1}(\mathrm{n}=11)$. Cough frequency was also significantly $(\mathrm{p}<0.01)$ reduced from $22.9 \pm 2.7$ to $17.7 \pm 4.1$ coughs $10 \mathrm{~min}^{-1} 5 \mathrm{~min}$ post-treatment. Cough challenge 15 and $30 \mathrm{~min}$ post-treatment gave cough frequencies not significantly different to control values at the same time-points (fig. 4).

\section{Discussion}

Fenspiride, whether given i.v. or as an aerosol, has proved to be an effective antibronchoconstrictor against capsaicin- and citric acid-induced bronchoconstriction in vitro, although the induced bronchoconstriction was not completely reversed. No effect was found on bronchoconstriction induced by i.v. administration of the neuropeptides, SP and NKA. Although Advenier [13] found spasmolytic action of fenspiride opposing the constriction of various agents, including SP and NKA, this study was in vivo using guinea-pig tracheal rings and the results may not be directly comparable to the present in vivo study. The observation that fenspiride had no effect on basal tone was confirmed by our own studies, where a fenspiride infusion produced no change in resting airways resistance.

We measured total airways resistance of the animal and not smooth muscle constriction directly and it is possibe that other factors, such as microvascular leakage, may have contributed to the resistance recorded. In the guinea-pig, microvascular leakage is induced by neurokinins principally acting on $\mathrm{NK}_{1}$ receptors and during inflammatory responses. Although the reported antiinflammatory actions of fenspiride could explain a decrease in plasma extrusion by the latter action, any inhibition of the former action (particularly induced by SP) was not reflected in a decrease in airways resistance.

O'NeILL [14], following a study of dorsal root ganglia, proposed that capsaicin in combination with a C-fibre membrane receptor, caused the opening of a nonspecific ion channel. The resulting inward movement of $\mathrm{Ca}^{2+}$ increased the intracellular $\mathrm{Ca}^{2+}$ pool triggering the release of neuropeptides, which could in turn lead to bronchoconstriction. It is most likely, although there is no direct evidence, that citric acid induces bronchoconstriction in a similar manner to capsaicin in the guineapig. SATOH et al. [15] showed that capsazeapine, a specific capsaicin antagonist, and SR48968, a specfic $\mathrm{NK}_{2}$ antagonist, inhibited citric acid-induced bronchoconstriction in the guinea-pigs. It is of note that we found that only constriction via the release of neurokinins from sensory $\mathrm{C}$-fibres and not exogenous neurokinin constriction was reduced by fenspiride. It is probable, therefore, that the action of fenspiride is mediated via an effect on the release or synthesis of neurokinins from the sensory $\mathrm{C}$ fibres, rather than an effect on the $\mathrm{NK}_{2}$ receptors responsible for tachykinin-induced bronchoconstriction. However, it is unlikely to be an effect on the synthesis of neurokinins, considering the acute administration of the drug and the rapid onset of the response to fenspiride. As the neurokinins released are rapidly degraded and there was 
no effect on SP and NKA evoked responses, the administration of fenspiride after the constictor agents is likely to lead to an underestimation of the reversal of capsaicin constriction. The inability to reduce constriction induced by means other than capsaicin and citric acid also suggests that fenspiride does not have a direct relaxant effect on bronchial smooth muscle fibres in vivo.

Although fenspiride has been shown to have an anti$\mathrm{H}_{1}$ action [1], there is no evidence that capsaicin bronchoconstriction is mediated via these receptors. There exists an axonal reflex initiating bronchoconstriction after $\mathrm{C}$ fibre stimulation in the guinea-pig [10], although in man this reflex is of a limited transient nature [11]. In these studies, at least part of this bronchoconstriction was shown to be cholinergic, and it is possible that an anticholinergic action of fenspiride was responsible for the alleviation of capsaicin-induced bronchoconstriction.

Aerosolized fenspiride showed an antitussive action against both capsaicin- and citric acid-induced cough in a dose-dependent manner. There was a shift in the citric acid dose response curve to the right. To calculate the absolute dose of fenspiride each individual animal received is difficult because of the variables of airway deposition and ventilation; however, the ventilation rate of the animal will profoundly affect the dose of citric acid inhaled and, thus, the cough response. Although we were unable to measure ventilation directly by the method of induction plethysmography (used during the cough challenge studies), the airflow trace showed no change in rate or depth with fenspiride treatment, which is in agreement with previous ventilation studies in rats [7].

Fenspiride is readily diffusible [16] and passes across the blood/brain barrier, and, therefore, could inhibit the cough reflex by a central action on the neural components of the reflex. However, no such general central nervous system depressent effect has been found with fenspiride, and it is also likely that a central action would require a higher concentration of the drug than a peripheral action induced by aerosol administration directly into the airways.

Aerosolized fenspiride was found to have a duration of action less than $15 \mathrm{~min}$. This relatively short duration was probably due to the rapid distribution of the drug [16], diffusion accounting for the removal from its site of action in the airways into the bronchial circulation. It may be possible to prolong the action by incorporation of the drug in a slow release formulation.

It has been suggested by HigenBotTAm [17] that citric acid stimulates the rapidly adapting vagal afferent receptors (RAR), whilst capsaicin is a stimulant of nonmyelinated C-fibres although an effect on small myelinated fibres cannot be ruled out. In order to reduce cough by an action at the receptor level, fenspiride, therefore, must have an action on one or both of these populations of vagal afferents. If the cough reflex is initiated by stimulation of membrane receptors with affinities for capsaicin and citric acid, then the action of fenspiride is unlikely to be one of direct membrane receptor antagonism for two such structurally different molecules. A common pathway for the involvement of capsaicin and hydrogen ions in opening ion channels which lead to the depolarization of rat dorsal root ganglia cells has been postulated by Bevan and Yeats [18]. However it is unclear whether hydrogen ions from citric acid dissociation constitute the mediator for the initiation of the cough reflex.

Recent work has shown that $\mathrm{NK}_{2}$ but not $\mathrm{NK}_{1}$ antagonists inhibit both citric acid- [19] and capsaicin-induced cough [20]. NKA has been shown to produce cough in guinea-pigs which was increased by phosphoramidon, a neutral endopeptidase inhibitor which reduces the breakdown of neurokinins [21]. Although a central action of the $\mathrm{NK}_{2}$ inhibitor cannot be ruled out, these studies may indicate a neurokinin involvement in chemically-induced cough, perhaps as an intermediary between chemical induction and action potential generation. Although the antitussive action of fenspiride mediated through neurokinin receptor inhibition is unlikely, as NKA-induced bronchoconstriction was unaffected, pathways for the release or synthesis of neurokinins may be affected.

In conclusion, whilst cough and bronchoconstriction are separate airway reflexes, it is possible that the antibronchoconstrictor and antitussive actions of fenspiride may be mediated by an inhibitory action on pathways common to both reflexes, e.g. the sensory $\mathrm{C}$-fibre. Further studies are necessary to differentiate between possible actions on ion movement across the receptor membrane and an action on the synthesis and release of neurokinins.

In the clinical situation, fenspiride, whilst maintaining its anti-inflammatory potential, may, through an antibronchoconstrictor action, prove more effective in those patients with a reversible component of airways disease. An antitussive action confers the added avantage of reducing the debilitating symptom of cough.

\section{References}

1. Evrard Y, Kato G, Bodinier MC, Chapelain B, . Fenspiride and inflammation in experimental pharmacology. Eur Respir Rev 1991; 1: 93-100.

2. Romanet $\mathrm{Ph}$, Stewart AG. Value of fenspiride in the treatment of inflammation diseases in otorhinolaryngology. Eur Respir Rev 1991; 1; 105-110.

3. Carre Ph, Pipy B, Pinelli E, et al. In vitro effect of fenspiride on the production of free oxygen radicals, prostoglandins and leukotrienes by guinea-pig alveolar macrophages. Eur Respir Rev 1991; 1; 79-85.

4. Broillet A, White R, Ventrone R, Gieissinger N. Efficacy of fenspiride in alleviating $\mathrm{SO}_{2}$-induced chronic bronchitis in rats and allergic rhinitis in guinea-pigs. Rhinology 1988; (Suppl. 4): 75-84.

5. Chapelain B, Neliat G, Bodinier NC, Jean T, Evrard Y, Gargouil HM. Role of the epithelium in the action of fenspiride on the isolated guinea-pigs and rat trachea. Eur Respir Rev 1991; 1: 86-92.

6. Akoun G, Arnaud F, Blanchon F, et al. Effects of fenspiride on airway function and blood gases in stable COPD patients. Eur Respir Rev 1991: 1; 111-125.

7. Bee D, Laude EA, Emery CJ, Howard P. The effect of fenspiride on pulmonary function in the rat and guineapigs. Clin Sci 1995; 88: 325-330.

8. Lundberg JM, Saria A, Theodorsson-Norheim E et al. Multiple tachykinins in capsaicin-sensitive afferents: 
occurrence, release and biological effects with special reference to irritation of the airways. In: Hakanson R, Sundler F, eds. Tachykinin Antagonists. Amsterdam, Elsevier Science Publishers BV (Biomedical Division, 1985; pp. 159-169.

9. Maggi CA. Tachykinin receptors and airway pathophysiology. Eur Respir J 1993; 6; 735-742.

10. Forsberg K, Karlsson JA, Theodorsson E, Lundberg JM Persson CGA. Cough and bronchoconstriction mediated by capsaicin-sensitive sensory neurons in the guineapig. Pulm Pharmacol 1988; 1: 33-39.

11. Fuller RW, Dixon CMS, Barnes PJ. Bronchoconstrictor response to inhaled capsaicin in humans. J Appl Physiol 1985; 58: 1080-1084.

12. Forsberg K, Karlsson JA, Zackrisson C, Persson CGA Selective inhibition of cough and bronchoconstriction in conscious guinea-pigs. Respiration 1992; 59; 72-76.

13. Advenier C. Fenspiride and relaxation of tracheobronchial musculature: mechanism of action. Rhinology 1988; (Suppl. 4): 67-74.

14. O'Neill TP. Mechanisms of action of capsaicin. Respir Med 1991; 85 (Suppl. A): 34-42.

15. Satoh H, Lou Y, Lundberg JM. Inhibitory effects of cap-sazepine and SR48968 on citric acid-induced bronchoconstriction in guinea-pigs. Eur J Pharmacol 1993; 236: 367-372.

16. Jeanniot JPh, Chezaubernard C. Pharmacokinetic properties of fenspiride: an update. Eur Respir Rev 1991; 1: 101-105.

17. Higenbottam T. Cough induced by changes of ionic composition of airway surface liquid. Bull Eur Physiopathol Respir 1984; 20; 553-562.

18. Bevan S, Yeats J. Protons activate a cation conductance in a subpopulation of rat dorsal root ganglion neurons. J Physiol 1991; 433: 145.

19. Advenier C, Girard V, Naline E, Vilain P, Emonds-Alt $\mathrm{X}$. Influence of SR48968, a neurokinin $\mathrm{NK}_{2}$ receptor antagonist on cough induced by citric acid in conscious guinea-pig. Am J Respir Crit Care Med. 1994; 149 (4): A186.

20. Robineau P, Petit C, Staczek J, Peglion JL, Brion JD, Canet E. $\mathrm{NK}_{1}$ and $\mathrm{NK}_{2}$ involvement in capsaicin-induced cough in guinea-pigs. Am J Respir Crit Care Med 1994; 149 (4): A186.

21. Takahama K, Fuchikama J, Isohama Y, Kai H, Miyata T. Neurokinin A but not neurokinin B and substance $\mathrm{P}$ induces codeine-resistant cough in awake guinea-pigs. Regul Pept 1992; (Suppl. 1); S154. 